\title{
A EDUCAÇÃO DE JOVENS E ADULTOS NO SÉCULO XXI - A EXPANSÃO DA EDUCAÇÃO A DISTÂNCIA E A FORMAÇÃO DO TUTOR
}

\author{
Gabriele Pilletti de Andrade* \\ Orientadora : Prof ${ }^{\mathrm{a}} \mathrm{Dr}^{\mathrm{a}}$ Desiré Luciane Dominschek
}

\begin{abstract}
Resumo
Na contemporaneidade, a cada dia surgem novas plataformas virtuais, e a Educação como desenvolvimento político e pedagógico, se apropria das intervenções da sociedade, que trazem novas bagagens de conhecimento e desenvolvimento humano para melhor compreensão dos acontecimentos cotidianos e científicos, que narram nossa história e fazem parte da nossa apropriação de cultura. Na educação superior a educação a distância, tem sido a oportunidade do ingresso a formação e continuidade educacional.
\end{abstract}

\section{Palavras-chave: \\ Educação a Distância; Tutor; Educação de Jovens e Adultos.}

\section{Introdução}

O professor que se situa, como docente na tutoria, vislumbra os pontos negativos e positivos, em que busca atingir seus objetivos na aplicação da rotatividade da atividade, mas também na dificuldade do acesso do aluno ao ambiente virtual. Ensinar a distância para jovens e adultos do EJA é compreender todo o processo emancipatório que se concretiza nos períodos da história, visto o respaldo e a importância que se tem dado ao "Ser" em processo de alfabetização, se encontrando como secundária e sem maior interesse do ponto de vista da formulação política e da reflexão pedagógica (Pierro, 2001). É preciso pensar não apenas como ocorre a alfabetização, mas como foi efetuada e legitimada. Como vemos historicamente, efetuou-se a passos largos e que hoje está se fragmentando, devido aos modelos econômicos e a inserção do jovem no mercado de trabalho. O artigo tem como fundamento analisar os processos que ocorreram a Educação de Jovens e Adultos buscando ressaltar as dificuldades que os alunos possuem, visto as demandas do século XXI, como a introdução do jovem no mercado de trabalho. Tratar das novas demandas deste século é imprescindível um olhar para a aprendizagem através das novas plataformas virtuais disponíveis e acessíveis. A Educação de Jovens e Adultos se encontra fragmentada, ou até tida como desnecessária na visão da Educação por EaD,

\section{Resultados e Discussão}

A ead é um campo que está em desenvolvimento e que encontra dificuldade tanto na acessibilidade e na permanência, levando em conta o outro viés, que é o do tutor, que prepara e orienta as rotas de aprendizagem para os alunos que estão em processo de alfabetização. 0 objetivo deste artigo foi retratar o tutor, e como é realizado seu trabalho para os jovens, com seus anseios e dificuldades, bem como os pontos positivos. Analisar a Educação de Jovens e Adultos a distância é encontrar dificuldades e retratar a desistência e/ou a persistência, mesmo com a dificuldade devido ao trabalho ou as relações sociais, mas também mostrar o quanto tem crescido e dado oportunidade de acesso ao ensino médio e a formação continuada.

\section{Conclusões}

$\mathrm{Na}$ educação superior a educação a distância, tem sido a oportunidade do ingresso a formação e continuidade educacional.O professor da educação superior que se situa como docente na tutoria, vislumbra os pontos negativos na dificuldade do acesso do aluno ao ambiente virtual e positivos da emancipação da Educação a todas as classes. Ensinar a distância para jovens e adultos é compreender todo o processo emancipatório que se concretiza nos períodos da história, visto o respaldo e a importância que se tem dado ao "Ser" em processo de alfabetização, se encontrando como secundária e sem maior interesse do ponto de vista da formulação política e da reflexão pedagógica (Pierro, 2001). É preciso pensar não apenas como ocorreu, mas como foi legitimada. Como vemos historicamente, efetuou-se a passos largos e que hoje está se fragmentando, devido aos modelos econômicos e a inserção do jovem no mercado de trabalho. O profissional da Educação a Distância precisa compreender o movimento da sociedade e como ela se estabelece, bem como olhar para o presente analisando o passado, através de um olhar humano e científico, assim o tutor, que é o profissional educacional no qual estará como mediador neste processo de transmissão e assimilação, conseguirá realizar um trabalho emancipatório.

DI PIERRO, Maria Clara, HADDAD, Sérgio.

Escolarização de jovens e adultos. Revista Brasileira de Educação, 2000, № 14.

FREIRE, Paulo. Educação como prática da liberdade. Rio de Janeiro, Paz e Terra, 2002.

MALANCHEN, Julia. Políticas de formação de professores a distância no brasil : uma análise crítica. - campinas, sp : autores associados, 2015. (coleção formação de professores). 